\title{
WPLYW WYBRANYCH CZYNNIKÓW NA WYDAJNOŚĆ EKSTRAKCJI I SKLAD KWASÓW TEUSZCZOWYCH OLEJU MIKROBIOLOGICZNEGO OTRZYMYWANEGO Z KOMÓREK DROŻDŻY YARROWIA LIPOLYTICA
}

\begin{abstract}
Streszczenie
Drożdże Yarrowia lipolytica to modelowy gatunek mikroorganizmów olejogennych, zdolny do kumulacji lipidów wewnątrz komórki w ilości powyżej 20 \% suchej masy. Oprócz prac nad zwiększaniem wydajności biosyntezy oleju mikrobiologicznego ważnym zagadnieniem jest także dobór warunków ekstrakcji tłuszczu z biomasy drożdży. Celem pracy była ocena wpływu wybranych parametrów (rodzaju rozpuszczalnika, sposobu przygotowania próbki oraz czasu trwania procesu) na wydajność ekstrakcji tłuszczu zawartego w komórkach dzikiego szczepu drożdży Y. lipolytica KKP 379, prowadzonej w aparacie Soxhleta oraz na skład kwasów tłuszczowych w uzyskanym oleju. Hodowle okresowe drożdży prowadzono w bioreaktorze laboratoryjnym $\mathrm{w}$ bogatym podłożu YPO oraz w podłożach mineralnych z limitowaną zawartością azotu, co umożliwiło otrzymanie biomasy komórkowej o zróżnicowanej zawartości oleju mikrobiologicznego. W badaniach zastosowano plany kwadratów łacińskich, co pozwoliło na odmaskowanie efektu wpływu sposobu przygotowania próbki na zmienną zależną, jaką była zawartość tłuszczu w biomasie drożdży. Najlepsze rezultaty osiągnięto po przygotowaniu biomasy metodą lityczną z wykorzystaniem komercyjnego preparatu Y-PER. Zastosowany czas ekstrakcji oraz rodzaj rozpuszczalnika (eter naftowy lub heksan) nie wpłynęły istotnie na wydajność procesu. Rodzaj rozpuszczalnika miał z kolei wpływ na zawartość trzech kwasów tłuszczowych spośród czternastu zidentyfikowanych w lipidach ekstrahowanych z biomasy drożdży, tj. kwasu palmitooleinowego, eikozapentaenowego i dokozatetraenowego. Większą zawartość wymienionych kwasów oznaczono w próbkach ekstrahowanych heksanem.
\end{abstract}

Słowa kluczowe: Yarrowia lipolytica, drożdże olejogenne, ekstrakcja ciągła, olej mikrobiologiczny, plany kwadratów łacińskich, kwasy tłuszczowe

Dr inż. A. Fabiszewska, Katedra Chemii, Wydz. Nauk o Żywności, inż. A. Pielińska, inż. P. Mazurczak, inż. B. Zieniuk, Wydz. Ogrodnictwa, Biotechnologii i Architektury Krajobrazu, Szkoła Główna Gospodarstwa Wiejskiego, ul. Nowoursynowska 159C, 02-776 Warszawa, mgr inż. M. Wołoszynowska, Zakład Analityczny, Instytut Przemystu Organicznego, ul. Annopol 6, 03-236 Warszawa.

Kontakt: agata_fabiszewska@sggw.pl 


\section{Wprowadzenie}

Ważnymi i często suplementowanymi składnikami żywności są wielonienasycone kwasy tłuszczowe pozyskiwane z materiału roślinnego lub zwierzęcego. Alternatywnym źródłem tych związków, choć nadal rzadko wykorzystywanym, są mikroorganizmy olejogenne. Olej mikrobiologiczny - ang. single cell oil (SCO), syntetyzowany wewnątrzkomórkowo przez mikroorganizmy ma skład zbliżony do wysokiej jakości olejów roślinnych, a hodowla mikroorganizmów jest szybka, niezależna od klimatu i wymaga mniejszego nakładu pracy w porównaniu z uprawą roślin czy chowem zwierząt $[1,9]$. Do mikroorganizmów olejogennych zdolnych do kumulacji substancji lipidowych w ilości powyżej $20 \%$ suchej biomasy komórki zaliczane są głównie grzyby (strzępkowe i drożdże) oraz kilka gatunków alg i bakterii [14]. Zdolność gromadzenia lipidów w komórkach drożdży z gatunku Yarrowia lipolytica, ich niepatogenność oraz dokładnie poznany genom sprawiły, że stały się one organizmem modelowym grupy drożdży olejogennych $[2,6,8]$.

Istotnym zagadnieniem produkcji oleju mikrobiologicznego jest dobór metod i warunków jego ekstrakcji z wnętrza komórek, które mogą decydować o końcowej jakości i właściwościach oleju. Ekstrakcję tłuszczów z komórek organizmów żywych przeprowadza się najczęściej metodą Folcha, stosując ekstrakcję prostą mieszaniną rozpuszczalników, takich jak chloroform i metanol. Powszechną metodą ekstrakcji ciągłej z próbek stałych - uznaną za standardową przez AOAC (ang. Association of Official Agricultural Chemists) - jest ługowanie w aparacie Soxhleta. Możliwe są również modyfikacje tej metody z wykorzystaniem mikrofal lub ultradźwięków. Innymi metodami wydzielania lipidów są ekstrakcja nadkrytyczna czy ekstrakcja rozpuszczalnikiem pod zwiększonym ciśnieniem [15], przy czym obecnie są one zbyt kosztowne do zastosowania w skali przemysłowej [1].

Celem niniejszej pracy była ocena wpływu wybranych czynników (rodzaju rozpuszczalnika, sposobu przygotowania próbki oraz czasu trwania procesu) na wydajność ekstrakcji oleju mikrobiologicznego syntezowanego w komórkach drożdży $Y$. lipolytica, prowadzonej w aparacie Soxhleta oraz na skład kwasów tłuszczowych w tak uzyskanym oleju.

\section{Material i metody badań}

Materiał biologiczny stanowił dziki szczep drożdży Y. lipolytica KKP 379 pochodzący z Kolekcji Kultur Drobnoustrojów Przemysłowych Instytutu Biotechnologii Przemysłu Rolno-Spożywczego im. prof. W. Dąbrowskiego w Warszawie. Szczep drożdży przechowywano na podłożu agarowym YPG zawierającym glukozę $20 \mathrm{~g} / \mathrm{dm}^{3}$, pepton $-20 \mathrm{~g} / \mathrm{dm}^{3}$, ekstrakt drożdżowy $-10 \mathrm{~g} / \mathrm{dm}^{3}$ oraz agar $-20 \mathrm{~g} / \mathrm{dm}^{3}$. Hodowle drożdży prowadzono $\mathrm{w}$ podłożach płynnych bez dodatku agaru: YPO 
(w którym glukozę zastąpiono oliwą z oliwek w ilości $20 \mathrm{~g} / \mathrm{dm}^{3}$ ), YPR (glukozę zastąpiono olejem odpadowym po procesie wędzenia ryb z rodziny łososiowatych i makrelowatych w ilości $20 \mathrm{~g} / \mathrm{dm}^{3}$ ), YPOR (po $10 \mathrm{~g} / \mathrm{dm}^{3}$ oliwy z oliwek i oleju odpadowego) oraz MO5 opracowanym na podstawie danych, które opublikowali Bialy i wsp. [3] oraz Papanikolaou i Aggelis [10] (oliwa z oliwek $-50 \mathrm{~g} / \mathrm{dm}^{3}$, Tween $80-1 \mathrm{~g} / \mathrm{dm}^{3}$, pepton $-1 \mathrm{~g} / \mathrm{dm}^{3}$, ekstrakt drożdżowy $-2 \mathrm{~g} / \mathrm{dm}^{3},\left(\mathrm{NH}_{4}\right)_{2} \mathrm{SO}_{4}-2,5 \mathrm{~g} / \mathrm{dm}^{3}, \mathrm{KH}_{2} \mathrm{PO}_{4}-$ $7 \mathrm{~g} / \mathrm{dm}^{3}, \mathrm{Na}_{2} \mathrm{HPO}_{4}-2,5 \mathrm{~g} / \mathrm{dm}^{3}, \mathrm{MgSO}_{4}-1,5 \mathrm{~g} / \mathrm{dm}^{3}, \mathrm{CaCl}_{2}-0,15 \mathrm{~g} / \mathrm{dm}^{3}, \mathrm{FeSO}_{4} \times \mathrm{H}_{2} \mathrm{O}$ $-0,16 \mathrm{~g} / \mathrm{dm}^{3}, \mathrm{ZnSO}_{4}-0,02 \mathrm{~g} / \mathrm{dm}^{3}, \mathrm{MnCl}_{2} \times 4 \mathrm{H}_{2} \mathrm{O}-0,08 \mathrm{~g} / \mathrm{dm}^{3}$ ). Początkowe $\mathrm{pH}$ podłoży ustalano na poziomie 5,0. Hodowle okresowe prowadzono w bioreaktorze laboratoryjnym BIOFLO 3000 (New Brunswick Scientific Edison, USA) o pojemności roboczej $4 \mathrm{dm}^{3}$ w temp. $28{ }^{\circ} \mathrm{C}$ przy obrotach mieszadła promieniowego $\mathrm{z}$ sześcioma łopatkami na poziomie $350 \mathrm{rpm}$ oraz natlenieniu sprężonym powietrzem. Objętość stosowanego inokulum wynosiła $0,0375 \%$ (v/v). Fazy wzrostu drożdży oceniano na podstawie stopnia zużycia tlenu rozpuszczonego w podłożu za pomocą elektrody tlenowej. Wartość powyżej 50 \% natlenienia oznaczała wejście komórek w fazę stacjonarną. Hodowle prowadzono do momentu osiągnięcia przez komórki fazy stacjonarnej.

Próbki mokrej biomasy $(30 \div 40 \mathrm{~g})$ przygotowywano czterema metodami: mechaniczną (próbkę biomasy drożdży ucierano w moździerzu z piaskiem), dezintegracji z wykorzystaniem detergentów (dodawano $15 \mathrm{~cm}^{3}$ handlowego preparatu litycznego Y-PER, Thermo Fisher Scientific, Waltham, USA), chemiczną (dodawano $30 \mathrm{~cm}^{3}$ acetonu i mieszano przez $30 \mathrm{~min}$ ), skojarzoną (łączono metodę mechaniczną z chemiczną). Przygotowaną biomasę suszono do zawartości wody $<0,5 \%$. Ekstrakcję oleju mikrobiologicznego wykonywano metodą ługowania w aparacie Soxhleta. W doświadczeniach stosowano dwa rozpuszczalniki: eter naftowy lub heksan. Czas ekstrakcji mierzono liczbą przelewów. Średni czas przelewu wynosił $8 \div 9 \mathrm{~min}$. Ekstrakt (olej mikrobiologiczny) oddzielano od rozpuszczalnika metodą destylacji pod zmniejszonym ciśnieniem (360 mbar) w wyparce próżniowej BÜCHI Rotavapor R-200 (Szwajcaria). Zawartość wyekstrahowanych lipidów z komórek obliczano na podstawie masy oleju w odniesieniu do naważki suchej biomasy drożdży.

Przeprowadzono dwa doświadczenia $\mathrm{z}$ uwzględnieniem statystycznego planowania doświadczeń z wykorzystaniem planu kwadratów łacińskich $4 \times 4$ oraz $2 \times 2$ (tab. 1 i 2). W pierwszym doświadczeniu wykorzystano biomasę drożdży $z$ hodowli w podłożu YPO, a w drugim - biomasę namnożoną w podłożu MO5 (o dużej zawartości oleju) oraz w podłożu YPR (o małej zawartości oleju).

Skład kwasów tłuszczowych w oleju mikrobiologicznym ekstrahowanym z biomasy drożdży hodowanej w podłożu YPOR oznaczano metodą chromatografii gazowej z zastosowaniem detektora płomieniowo-jonizacyjnego. Zhydrolizowane kwasy thuszczowe w oleju poddawano derywatyzacji do postaci estrów metylowych przy użyciu $1 \mathrm{M}$ metanolanu sodu oraz 14-procentowego $\mathrm{BF}_{3} \mathrm{w}$ metanolu. Do analiz używano apa- 
ratu firmy Varian CP3800 (USA) wyposażonego w kolumnę kapilarną ZB-FFAP o długości $30 \mathrm{~m}$, średnicy wewnętrznej $0,25 \mathrm{~mm}$ i grubości filmu fazy stacjonarnej $0,25 \mu \mathrm{m}$. Jako gaz nośny stosowano hel. Przepływ gazu nośnego wynosił $1,2 \mathrm{~cm}^{3} / \mathrm{min}$. Poszczególne kwasy thuszczowe identyfikowano na podstawie czasów retencji, porównując je z kwasami wzorcowymi.

Tabela 1. Plan pierwszego doświadczenia - kwadrat łaciński $4 \times 4$

Table 1. First experiment design - Latin Square Design $4 \times 4$

\begin{tabular}{|c|c|c|c|c|}
\hline \multirow{2}{*}{$\begin{array}{l}\text { Liczba } \\
\text { przelewów } \\
\text { Number of } \\
\text { overflows }\end{array}$} & \multicolumn{4}{|c|}{ Rodzaj rozpuszczalnika / Type of solvent } \\
\hline & $\begin{array}{l}\text { Eter naftowy } \\
\text { Petroleum ether }\end{array}$ & $\begin{array}{l}\text { Eter naftowy } \\
\text { Petroleum ether }\end{array}$ & $\begin{array}{l}\text { Heksan } \\
\text { Hexane }\end{array}$ & $\begin{array}{l}\text { Heksan } \\
\text { Hexane }\end{array}$ \\
\hline 6 & Y-PER & $\begin{array}{c}\text { Piasek } \\
\text { Grit }\end{array}$ & $\begin{array}{l}\text { Metoda skojarzona } \\
\text { Associated method }\end{array}$ & $\begin{array}{l}\text { Aceton } \\
\text { Acetone }\end{array}$ \\
\hline 10 & $\begin{array}{l}\text { Metoda skojarzona } \\
\text { Associated method }\end{array}$ & $\begin{array}{l}\text { Aceton } \\
\text { Acetone }\end{array}$ & Y-PER & $\begin{array}{c}\text { Piasek } \\
\text { Grit }\end{array}$ \\
\hline 14 & $\begin{array}{c}\text { Piasek } \\
\text { Grit }\end{array}$ & $\begin{array}{l}\text { Metoda } \\
\text { skojarzona } \\
\text { Associated } \\
\text { method }\end{array}$ & $\begin{array}{l}\text { Aceton } \\
\text { Acetone }\end{array}$ & Y-PER \\
\hline 18 & $\begin{array}{l}\text { Aceton } \\
\text { Acetone }\end{array}$ & Y-PER & $\begin{array}{c}\text { Piasek } \\
\text { Grit }\end{array}$ & $\begin{array}{c}\text { Metoda } \\
\text { skojarzona } \\
\text { Associated } \\
\text { method }\end{array}$ \\
\hline
\end{tabular}

Objaśnienia / Explanatory notes:

Czynnik badany - sposób przygotowania próbki / Factor being tested - sample treatment method.

Tabela 2. Plan drugiego doświadczenia - kwadrat łaciński $2 \times 2$

Table 2. Second experiment design - Latin Square Design $2 \times 2$

\begin{tabular}{||c|c|c||}
\hline \multirow{2}{*}{$\begin{array}{c}\text { Sposób przygotowania próbki } \\
\text { Sample treatment method }\end{array}$} & \multicolumn{2}{|c||}{ Zawartość tłuszczu w biomasie / Content of lipids in biomass } \\
\cline { 2 - 3 } & $\begin{array}{c}\text { Biomasa o dużej zawartości } \\
\text { tłuszczu / Biomass with high } \\
\text { lipid content }\end{array}$ & $\begin{array}{c}\text { Biomasa o małej zawartości } \\
\text { thuszczu / Biomass with low } \\
\text { lipid content }\end{array}$ \\
\hline $\begin{array}{c}\text { Brak przygotowania } \\
\text { No treatment }\end{array}$ & 6 & 18 \\
\hline $\begin{array}{c}\text { Y-PER lub metoda skojarzona } \\
\text { Y-PER or associated method }\end{array}$ & 18 & 6 \\
\hline
\end{tabular}

Objaśnienia / Explanatory notes:

czynnik badany - liczba przelewów / Factor being tested - number of overflows. 
Statystyczne opracowanie wyników przeprowadzono z wykorzystaniem oprogramowania Statistica 12.0 zestaw plus (Statsoft, Polska). Wyniki zawartości poszczególnych kwasów tłuszczowych analizowano za pomocą jednoczynnikowej analizy wariancji oraz przy zastosowaniu testu post-hoc Tukeya $(\mathrm{p}=0,05)$. Założenie o normalności rozkładu sprawdzono testem Shapiro-Wilka, a założenie o jednorodności wariancji - testem Levena.

\section{Wyniki i dyskusja}

Wpływ wybranych czynników na ilość uzyskiwanego oleju mikrobiologicznego metoda ekstrakcji ciaglej $w$ aparacie Soxhleta

W pierwszym doświadczeniu zbadano wpływ rodzaju rozpuszczalnika organicznego, sposobu przygotowania próbki biomasy drożdży oraz czasu ekstrakcji mierzonego liczbą przelewów na wydajność procesu ekstrakcji, czyli na ilość tłuszczu wydzielonego z komórek drożdży $Y$. lipolytica. Wyniki doświadczenia przedstawiono w formie wykresu efektów głównych na rys. 1. Zawartość lipidów w komórkach drożdży ekstrahowanych za pomocą eteru naftowego $(1,2)$ oraz heksanu $(3,4)$ nie różniła się w sposób statystycznie istotny i wynosiła odpowiednio: 0,032 i $0,033 \mathrm{~g} / \mathrm{g}$ s.s. Podobnie liczba przelewów nie miała istotnego wpływu na badaną cechę, choć największą zawartość tłuszczu (0,036 g/g s.s.) uzyskano przy 18 przelewach ekstrakcji ciągłej. Wykazano także brak istotnego wpływu sposobu przygotowania próbki na zawartość tłuszczu w komórkach drożdży, choć tutaj największą zawartość oleju uzyskano z biomasy traktowanej preparatem Y-PER $(0,038 \mathrm{~g} / \mathrm{g}$ s.s). Sformułowano zatem przypuszczenie, że czynnikiem zakłócającym w doświadczeniu mogła być mała zawartość thuszczu w namnożonej biomasie drożdży, która uniemożliwiła zaobserwowanie różnic w wartościach zmiennej zależnej, mimo zróżnicowania poziomów czynników badanych.

Czynnikami sprzyjającymi magazynowaniu lipidów w komórce są: obniżenie poziomu dostępności źródła azotu oraz obecność w podłożu kwasów tłuszczowych lub triacylogliceroli. W podłożu YPO znajdowała się oliwa z oliwek jako lipidowe źródło węgla oraz duża zawartość peptonu jako źródło azotu. Jak podają Papanikolaou i Aggelis [12], zwiększona zawartość źródła azotu wpływa negatywnie na końcową wydajność biosyntezy oleju mikrobiologicznego. Największą zawartość tłuszczu w komórkach drożdży Y. lipolytica w niniejszej pracy, na poziomie $0,35 \mathrm{~g} / \mathrm{g}$ s.m. drożdży, uzyskano w podłożu mineralnym MO5 zawierającym ograniczoną ilość azotu. W podłożu YPR, stanowiącym bogate źródło azotu, zawartość thuszczu wewnątrzkomórkowego była znacząco mniejsza - 0,002 g/g s.m. Przy okazji wykazano, jak ważną rolę w mikrobiologicznej syntezie odgrywają warunki hodowli mikroorganizmów, co znajduje także potwierdzenie $\mathrm{w}$ innych badaniach nad akumulacją substancji lipido- 
wych wewnątrz komórek drożdży w warunkach wyczerpania źródła azotu w podłożu hodowlanym $[3,10,13]$.

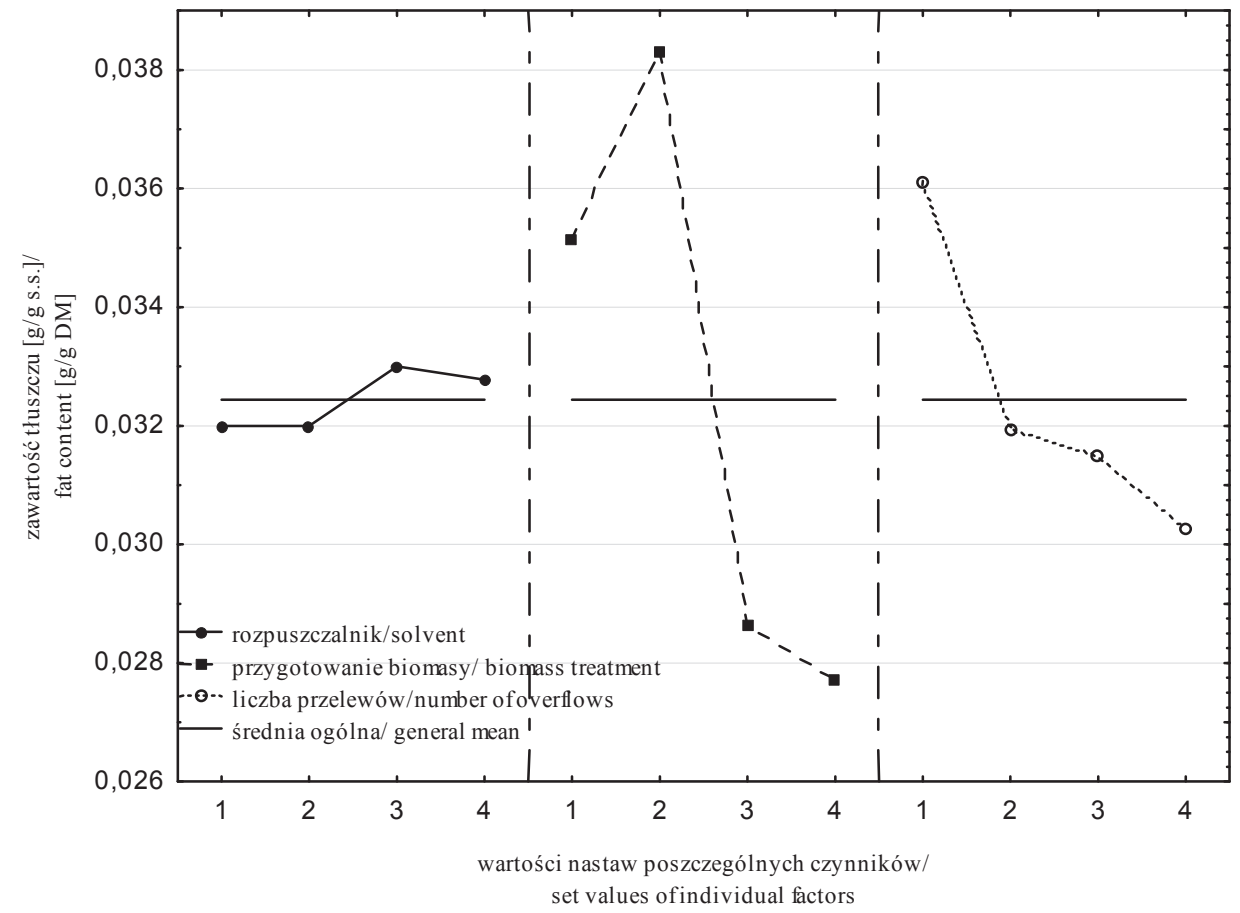

Objaśnienia / Explanatory notes:

Wartości nastaw czynników: / Set values of individual factors: rozpuszczalnik: / solvent: 1, 2 - eter naftowy / petroleum ether, 3, 4 - heksan / hexane; sposób przygotowania próbek: / sample treatment method: 1 - aceton / acetone, 2 - Y-PER; 3 - piasek / grit, 4 - metoda skojarzona / associated method; liczba przelewów: / number of overflows: $1-18,2-14,3-10,4-6$.

Rys. 1. Wykres efektów głównych doświadczenia na bazie kwadratu łacińskiego $4 \times 4$

Fig. 1. Diagram of main effects for experiment based on Latin Square Design $4 \times 4$

W drugim doświadczeniu dodatkowym badanym czynnikiem był rodzaj biomasy drożdży, z której ekstrahowano lipidy. Ponownie posłużono się planem kwadratów łacińskich, stosowanym, gdy efekt badanego czynnika jest silnie maskowany wpływami dominujących czynników zakłócających, które są znane i mogą być kontrolowane. Oceniono wpływ początkowej zawartości lipidów w biomasie drożdży oraz sposobu przygotowania próbek na wydajność procesu ekstrakcji (rys. 2). 


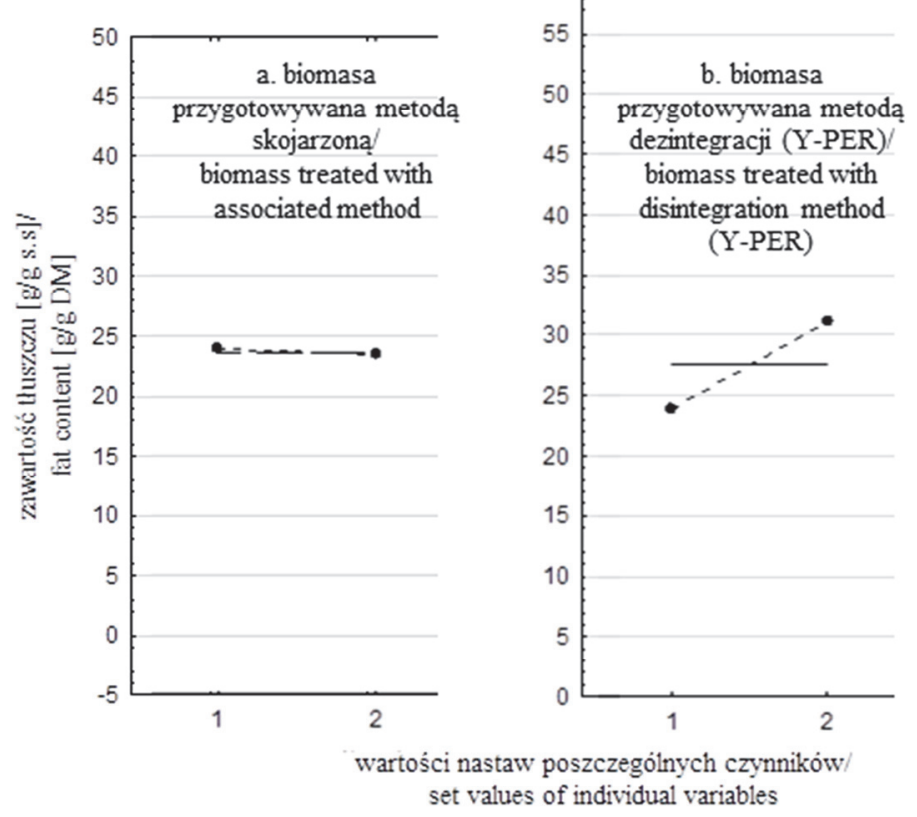

Objaśnienia / Explanatory notes:

Wartości nastaw: sposób przygotowania próbek:/ Set values: method of sample treatment: 1 - brak przygotowania / no treatment; 2 - metoda skojarzona (a) lub dezintegracji (preparat Y-PER) (b) / associated method (a) or disintegration method (Y-PER preparation) (b).

Rys. 2. Wykres efektów głównych doświadczenia $2 \times 2$ układu z biomasą przygotowywaną: a - metodą skojarzoną, $b$ - metodą dezintegracji (preparat Y-PER)

Fig. 2. Diagram of main effects for experiment based on $2 \times 2$ design with biomass treated: a - with associated method, $\mathrm{b}-$ with disintegration method (Y-PER preparation)

Zaplanowano dwa układy. W pierwszym biomasę niepoddaną przygotowaniu porównywano z biomasą, wobec której stosowano metodę skojarzoną (rys. 2a), a w drugim - preparat lityczny Y-PER (rys. 2b). Na rys. 2a. przedstawiono wykres efektów głównych doświadczenia, w którym zastosowano wariant biomasy przygotowanej do ekstrakcji poprzez jednoczesne mechaniczne rozcieranie piaskiem oraz działanie na komórki acetonem. Wyniki próbek bez przygotowania oraz tych, w których na próbki działano metodą skojarzoną były zbliżone (ok. $0,024 \mathrm{~g} / \mathrm{g}$ s.s.) i nie różniły się statystycznie istotnie. Istotnie wyższą wydajność ekstrakcji $(0,312 \mathrm{~g} / \mathrm{g}$ s.s.) uzyskano po zastosowaniu preparatu litycznego $\mathrm{w}$ stosunku do biomasy nieprzygotowanej $(0,239 \mathrm{~g} / \mathrm{g}$ s.s. $)$.

Podsumowując oba układy, można stwierdzić, że etap przygotowania biomasy drożdży do procesu ekstrakcji poprzez działanie preparatem litycznym Y-PER wpłynął 
na poprawę wyniku ługowania w sposób statystycznie istotny, a metoda skojarzona okazała się nieskuteczna w odniesieniu do ilości uzyskiwanego oleju. W drugim doświadczeniu wykazano statystycznie istotny wpływ tego czynnika na badaną cechę i stwierdzono maskujący efekt początkowej zawartości tłuszczu w komórce. Zastosowana metoda kwadratów łacińskich okazała się dogodną metodą statystyczną służącą do planowania i podsumowania wyników doświadczeń o niewielkim stopniu skomplikowania, co także sugerują w swojej pracy van Derlinden i wsp. [4].

Warto podkreślić, że zniszczenie ściany komórkowej drożdży lub jej permeabilizacja (zwiększenie przepuszczalności) to ważny etap mający na celu ułatwienia przenikania rozpuszczalnika do wnętrza komórek. Metody mechaniczne należą do najtańszych sposobów dezintegracji komórek, ale charakteryzują się niską selektywnością działania. Metody chemiczne (z użyciem rozpuszczalników lub związków powierzchniowo czynnych) i enzymatyczne są technikami generującymi wyższe koszty, a ich zastosowanie ogranicza się w dużej mierze do skali laboratoryjnej, pomimo że ich działanie jest specyficzne [7]. Brak jest niestety doniesień o badaniach wpływu metod przygotowania próbek do podobnych analiz. Według wiedzy autorów nie istnieją także podobne badania wpływu początkowej zawartości tłuszczu w komórce na sam proces ekstrakcji, a zatem nie jest możliwe ich porównanie.

Wpływ wybranych warunków ekstrakcji na skład kwasów tluszczowych w oleju mikrobiologicznym drożdży Y. lipolytica

Jedną z kluczowych zalet pozyskiwania tłuszczów z komórek mikroorganizmów jest możliwość precyzyjnego sterowania składem kwasów tłuszczowych triacylogliceroli wchodzących w skład oleju mikrobiologicznego. Dobierając odpowiednio szczep i gatunek mikroorganizmu, sterując składem pożywki hodowlanej oraz warunkami hodowli można uzyskać olej mikrobiologiczny wzbogacony w dowolne kwasy tłuszczowe $[3,10]$.

Już na etapie przygotowania materiału biologicznego oraz w czasie procesu ekstrakcji może dochodzić do pewnych zmian w składzie kwasów tłuszczowych ekstrahowanych tłuszczów. W tab. 3. przedstawiono skład kwasów tłuszczowych w lipidach ekstrahowanych z biomasy za pomocą dwóch różnych rozpuszczalników. Zawartość kumulowanego tłuszczu oraz jego skład różnią się w zależności od szczepu Y. lipolyti$c a$, a komórki mogą kumulować selektywnie kwasy thuszczowe (tzw. synteza ex novo) w ciałkach lipidowych w zależności od składu podłoża hodowlanego [2, 11], dlatego autorom pracy zależało na hodowli biomasy w podłożu zawierającym równocześnie dwa różne oleje jako źródło węgla: oliwę z oliwek oraz olej odpadowy po procesie wędzenia ryb. Oleje te cechowały się odmiennym składem kwasów tłuszczowych [5] i dlatego możliwa była ocena wpływu zastosowanego rozpuszczalnika na profil szerokiej gamy tych związków (tab. 3). Zaobserwowano, że rodzaj rozpuszczalnika (eter 
naftowy i heksan) miał istotny wpływ na zawartość trzech spośród czternastu kwasów thuszczowych zidentyfikowanych w lipidach drożdży, tj. na zawartość kwasu palmitooleinowego, eikozapentaenowego i dokozatetraenowego. Większą zawartość wymienionych kwasów oznaczano w próbkach ekstrahowanych heksanem. Wszystkie te kwasy miały co najmniej jedno wiązanie nienasycone w cząsteczce. Wpływ heksanu na ekstrakcję nienasyconych kwasów tłuszczowych wymaga z pewnością dalszych badań.

Tabela 3. Skład kwasów tłuszczowych oleju mikrobiologicznego ekstrahowanego z drożdży Yarrowia lipolytica przy użyciu dwóch rozpuszczalników [\% sumy wszystkich kwasów tłuszczowych]

Table 3. Composition of fatty acids in microbial oil extracted from Yarrowia lipolytica yeasts using two different solvents [\% of total of all fatty acids]

\begin{tabular}{|c|c|c|c|c|}
\hline \multirow{3}{*}{$\begin{array}{l}\text { Kwasy thuszczowe } \\
\text { Fatty acids }\end{array}$} & \multicolumn{4}{|c|}{ Rodzaj rozpuszczalnika / Type of solvent } \\
\hline & \multicolumn{2}{|c|}{$\begin{array}{c}\text { Eter naftowy / Petroleum } \\
\text { ether }\end{array}$} & \multicolumn{2}{|c|}{ Heksan / Hexane } \\
\hline & $\overline{\mathrm{x}}$ & $\mathrm{s} / \mathrm{SD}$ & $\overline{\mathrm{x}}$ & $\mathrm{s} / \mathrm{SD}$ \\
\hline $\begin{array}{l}\text { C14:0 (kwas mirystynowy) } \\
\text { C14:0 (myristic acid) }\end{array}$ & 0,10 & 0,10 & 0,65 & 0,45 \\
\hline $\begin{array}{l}\text { C14:1 (kwas tetradecenowy) } \\
\text { C14:1 (tetradecenoic acid) }\end{array}$ & 0,10 & 0,10 & 0,10 & 0,10 \\
\hline $\begin{array}{l}\text { C16:0 (kwas palmitynowy) } \\
\text { C16:0 (palmitic acid) }\end{array}$ & 10,85 & 1,95 & 5,65 & 3,05 \\
\hline $\begin{array}{l}\text { C16:1 (kwas palmitooleinowy) } \\
\text { C16:1 (palmitoleic acid) }\end{array}$ & $2,40 *$ & 0,80 & $7,10^{*}$ & 2,00 \\
\hline $\begin{array}{l}\text { C18:0 (kwas stearynowy) } \\
\text { C18:0 (stearic acid) }\end{array}$ & 3,50 & 1,40 & 6,00 & 2,00 \\
\hline $\begin{array}{l}\text { C18:1 (kwas oleinowy) } \\
\text { C18:1 (oleic acid) }\end{array}$ & 54,80 & 6,30 & 59,95 & 3,15 \\
\hline $\begin{array}{l}\text { C18:2 (kwas linolowy) } \\
\text { C18:2 (linoleic acid) }\end{array}$ & 16,90 & 5,70 & 10,60 & 3,10 \\
\hline $\begin{array}{l}\text { C18:3 (kwas linolenowy) } \\
\text { C18:3 (linolenic acid) }\end{array}$ & 3,70 & 1,60 & 2,55 & 0,55 \\
\hline $\begin{array}{l}\text { C20:1 (kwas eikozenowy) } \\
\text { C20:1 (eicosenic acid) }\end{array}$ & 0,70 & 0,50 & 0,15 & 0,05 \\
\hline $\begin{array}{l}\text { C20:5 (kwas eikozapentaenowy; EPA) } \\
\text { C20:5 (eicosapentaenoic acid, EPA) }\end{array}$ & $0,10^{*}$ & 0,10 & $0,80 *$ & 0,40 \\
\hline $\begin{array}{l}\text { C22:0 (kwas behenowy) } \\
\text { C22:0 (behenic acid) }\end{array}$ & 0,90 & 0,30 & 0,40 & 0,20 \\
\hline $\begin{array}{l}\text { C22:1 (kwas erukowy) } \\
\text { C22:1 (erucic acid) }\end{array}$ & 1,20 & 1,10 & 0,05 & 0,05 \\
\hline $\begin{array}{l}\text { C22:4 (kwas dokozatetraenowy) } \\
\text { C22:4 (docosatetraenoic acid) }\end{array}$ & $0,55^{*}$ & 0,25 & $3,70^{*}$ & 0,30 \\
\hline $\begin{array}{l}\text { C22:6 (kwas dokozaheksaenowy; DHA) } \\
\text { C22:6 (docosahexaenoic acid, DHA) }\end{array}$ & 1,15 & 0,75 & 2,20 & 0,10 \\
\hline
\end{tabular}

Objaśnienia / Explanatory notes:

$\overline{\mathrm{x}}$ - wartość średnia / mean value; $\mathrm{s}$ - odchylenie standardowe / SD - standard deviation.

* - różnice statystycznie istotne / *statistically significant differences. 


\section{Wnioski}

1. Najskuteczniejszą z badanych metodą przygotowania próbki do ekstrakcji była dezintegracja komórek z wykorzystaniem detergentów za pomocą preparatu litycznego Y-PER w porównaniu z metodą chemiczną, mechaniczną oraz skojarzoną.

2. Rodzaj użytego rozpuszczalnika organicznego oraz czas ekstrakcji liczony liczbą przelewów w aparacie Soxhleta nie miały istotnego wpływu na wydajność procesu w przeprowadzonym układzie doświadczalnym.

3. Rodzaj rozpuszczalnika miał istotny wpływ na zawartość jedynie trzech spośród czternastu kwasów tłuszczowych zidentyfikowanych w lipidach drożdży, większą zawartość nienasyconych kwasów: palmitooleinowego, eikozapentaenowego i dokozatetraenowego oznaczono w próbkach ekstrahowanych heksanem.

4. Zawartość tłuszczu w komórkach okazała się czynnikiem maskującym w badaniach; zastosowanie statystycznych metod planowania doświadczenia umożliwiło „odmaskowanie” efektu wpływu sposobu przygotowania próbki na zmienną zależną, jaką była zawartość tłuszczu w biomasie drożdży.

\section{Literatura}

[1] Ageitos J.M., Vallejo J.A., Veiga-Crespo P., Villa T.: Oily yeasts as oleaginous cell factories. Appl. Microbiol. Biotechnol., 2011, 90, 1219-1227.

[2] Beopoulos A., Cescut J., Haddouche R., Uribelarrea J.L., Molina-Jouve C., Nicaud J.M.: Yarrowia lipolytica as a model for bio-oil production. Prog. Lipid Res., 2009, 48 (6), 375-387.

[3] Bialy H.E., Gomaa O.M., Azab K.S.: Conversion of oil waste to valuable fatty acids using oleaginous yeast. World J. Microbiol. Biotechnol., 2011, 27, 2791-2798.

[4] Van Derlinden E., Mertens L., van Impe J.F.: The impact of experiment design on the parameter estimation of cardinal parameter models in predictive microbiology. Food Control, 2013, 29 (2), 300-308.

[5] Fabiszewska A., Mazurczak P., Pielińska A., Zieniuk B., Nowak D., Białecka-Florjańczyk E.: Próba zastosowania szczepu drożdży Y. lipolytica KKP 379 w zagospodarowaniu odpadów z zakładów przemysłu rybnego. Post. Techn. Przetw. Spoż., 2014, 2, 28-33.

[6] Fickers P., Benetti P.H., Waché Y., Marty A., Mauersberger S., Smit M.S., Nicaud J.M.: Hydrophobic substrate utilisation by the yeast Yarrowia lipolytica, and its potential applications. Yeast Res., 2005, 5, 527-543.

[7] Klimek-Ochab M., Brzezińska-Rodak M., Żymańczyk-Duda E., Lejczak B., Kafarski P.: Comparative study of fungal cell disruption - scope and limitations of the methods. Folia Microbiologica, 2011, 56 (5), 469-475.

[8] Krzyczkowska J., Fabiszewska A.: Yarrowia lipolytica - niekonwencjonalne drożdże w biotechnologii. Postępy Mikrobiologii, 2015, 54 (1), 33-43.

[9] Liang M., Jiang J.: Advancing oleaginous microorganism to produce lipid via metabolic engineering technology. Prog. Lipid Res., 2013, 52, 395-408.

[10] Papanikolaou S., Aggelis G.: Lipid production by Yarrowia lipolytica growing on industrial glycerol in a single-stage continuous culture. Bioresour. Technol., 2002, 82 (1), 43-49.

[11] Papanikolaou S., Aggelis G.: Lipids of oleaginous yeasts. Part I: Biochemistry of single cell oil production. Eur. J. Lipid Sci. Technol., 2011, 113 (8), 1031-1051. 
[12] Papanikolaou S., Aggelis G.: Lipids of oleaginous yeasts. Part II: Technology and potential applications. Eur. J. Lipid Sci. Technol., 2011, 113 (8), 1052-1073.

[13] Ratledge C.: Fatty acid biosynthesis in microorganisms being used for single cell oil production. Biochimie, 2004, 86 (11), 807-815.

[14] Ratledge C.: Microbial oils: An introductory overview of current status and future prospects. OCL, 2013, 20 (6), D602, 1-7.

[15] Carrasco-Pancorbo A., Navas-Iglesias N., Cuadros-Rodriguez L.: From lipid analysis towards lipidomics, a new challenge for the analytical chemistry of the $21^{\text {st }}$ century. Part I: Modern lipid analysis. TrAC, 2009, 28 (3), 263-278.

\title{
IMPACT OF SELECTED FACTORS ON EXTRACTION YIELD AND COMPOSITION OF FATTY ACIDS IN MICROBIAL OIL PRODUCED FROM YARROWIA LIPOLYTICA YEAST CELLS
}

\author{
$\mathrm{S}$ u m m a ry
}

Yarrowia lipolytica yeasts are a model species of oleaginous microorganisms capable of accumulating lipids inside the cell in an amount exceeding $20 \%$ of dry matter. In addition to studies on how to increase the efficiency of oil biosynthesis, an important issue is, also, the selection of conditions for lipid extraction from yeast biomass. The objective of the research study was to assess the impact of some selected parameters (type of solvent, sample treatment method, and the duration of the process) on the yield of extraction, run in an Soxhlet extractor, of lipids contained in cells of wild strain of Y. lipolytica KKP 379 yeast, and on the composition of fatty acids in the microbial oil produced. The yeasts were cultured in a batch process, in a laboratory bioreactor in a rich YPO medium, as well as in nitrogen restricted mineral media; thus, it was possible to obtain a cell biomass with varying contents of microbial oil. In the research, Latin Square Designs were applied so that the effect of biomass treatment method could be unmasked on the dependent variable, i.e. the content of lipids in the yeast biomass. The best results were achieved when the biomass was prepared using a commercial preparation of Y-PER. The applied duration time of extraction and the used type of solvent (petroleum ether or hexane) did not significantly impact the process yield. However, the type of solvent impacted the content of three fatty acids of the fourteen identified in the lipids extracted from the yeast biomass, ie. the content of palmitoleic, eicosapentaenoic, and docosatetraenoic acids. Higher contents of the above mentioned compounds were determined in the hexane extracted samples.

Key words: Yarrowia lipolytica, oleaginous yeasts, continuous extraction, microbial oil, Latin Square Designs, fatty acids 